\title{
The Effect of Using Gymnastics Games at the Level of Social Interaction, Fitness and Learn some Gymnastics Skills Children with Hearing Disabilities *Dr /Dalia mohammed Marouf mohammed
}

Introduction and research problem

The general aim of the State is to ensure equal educational opportunities for all healthy and disabled children. It is necessary to pay attention to the development of integrated and developed programs and activities in line with the needs, characteristics of disabled and healthy children in order to provide them with opportunities for integrated growth in order to become healthy individuals in all physical, psychological, mental and social aspects.

And through the adoption of the human senses that receive the information which is the world of cognitive and intellectual perception, and that the hearing is very important in human life, which is one of the foundations in the process of communication and interaction between humans and the environment in which they live,

To the others easily, expands the circle of information about the outside world, and therefore the loss of this feeling affects significantly on the personal aspects of many of the Deaf (general), because it feels the lack of the presence of others, where with them without feeling the role in this presence, and without being Has the ability to play Which leads to an inability to adapt outside of the pool.

Hassan Al-Bata (2010) noted that the issue of educating and rehabilitating people with special needs represents a civilizational challenge to nations and societies, because it is a humanitarian issue in the first place. It can impede the progress of nations, considering that persons with disabilities represent at least $10 \%$ of the total population at

Lecturer in Department of Rhythmic Exercises and Artistic Gymnastics, Faculty of Physical Education for Girls, Gizera, Giza, Helvan University

Assiut Journal For Sport Science Arts 
the local and international levels. The number of disabled people in the world is 600 million, more than $80 \%$ of them in developing countries.

No matter how different the statistics and the discrepancy of figures, the biggest problem is the small number of people receiving services and care in developing countries. Only $1.9 \%$ of those with special needs receive services.

Governmental organizations, in addition to the fact that their costs are very high.

It requires training, residency and staff, which requires the need for cooperation and social cohesion among all groups in the care of people with special needs, and the search for donors to try to include these groups, the majority of whom are poor and lowDevelopment rather than being dependent on it. (6:1)

Helmi Ibrahim and Laila Farhat (2008) note that the hearing impaired are considered to be the group that has suffered and continues to suffer from the lack of enjoyment of life with the normal ones because the sense of hearing is a way for people to know about their social environment. With the environment on an audio basis (7: 95.)

The statistics indicate that there is a steady increase in the number of students with hearing disabilities enrolled in the schools of audio education for their peers from other categories, whether intellectual or visual. However, if the number of hearing impaired enrolled in the schools of audio education in Egypt reached 5759 people in 1990 ,

This census has increased by 8507 In 1995, an increase of about 2748 people with hearing impairments. World statistics also indicated that 8 per thousand children up to age 20 had hearing impairment ranging from weak hearing loss to total loss of hearing. Here is the need for more attention from educational institutions, regular or informal, to take care of this category $(20: 3$.)

Mohammed Bayoumi Khalil (2003) states that those who oppose the planning and building of programs and curricula of deaf students must have full knowledge of the deaf student's abilities, abilities, tendencies, interests and trends 
as well as the nature of his mental, social and emotional development and his balance of past experiences. Which dealt with various aspects of growth experienced by the deaf and the extent of the impact of deafness on the nature of mental processes, because the knowledge of planners and implementers of the deaf curricula in these different aspects will make them put their hands on the key deaf person so they can access to the world of the deaf to learn the best factors and conditions that can facilitate the process of learning to translate all of this in the form of programs and curricula adapted to the nature of the deaf (21: 91.)

Children who are deaf or deaf can learn the activities and skills of the motor successfully both individually and collectively, but rather the extent to which the teacher understands their situation. It is possible to stimulate them to practice sports competition such as football or volleyball, especially if they are old and young children, (4: 302, 303), and the different types of patterns،

Sports is an important field in the development and rehabilitation of people with special needs, physically, psychologically, socially and professionally, and help them to re-establish contact with society through the development of their own programs. (74: 1)

Sahar Shehata (2008) emphasizes that the deaf child has the ability and energy to play and the dynamic performance of some motor activities can outweigh the average person, so that they are distinguished by the safety of their organs and their remaining senses. They also enjoy good physical fitness as movement is a means of expressing oneself they have, but lack many ingredients in the speed of learning, where he sees many different stimuli. (74:11)

Social interaction is a process of participation between children in life situations that helps in establishing relationships with others in the psychological field. It includes three main factors: social attention, social attention and social communication. Children with mental disabilities suffer from a clear lack of communication skills, social or personal skills; 
In addition, they are characterized by withdrawal from attitudes and interactions, which makes their social performance clearly low. In addition, they find it very difficult to adapt to new situations where their behavior is rigid, They do not care about the composition of social relations with others, especially with children of the same age and that time they tended to share the younger children in some social practices $(25: 2)$

It is worth mentioning that social skills are concerned with the social interaction among children, which are the skills that each person needs to communicate effectively with those around him, such as "emotional balance, communication, self-care, family life, social life, health and safety, self-direction" Social behavior is negative, which transforms the mentally handicapped child into the possibility of efficient coexistence with others, especially the ordinary.

The disabled child often resorted to aggressive behaviors, disorders and negative behavioral deviations due to the frustrations of his life It may be more prone to suffering from social ostracism and a sense of inferiority and inferiority. Therefore, it decreases its self-esteem. It may come with anti-social behaviors. It may suffer from many mental, behavioral and emotional disorders, mainly in the first place to his lack of social communication skills (16: 3)

Gymnastics is a kind of self-indulgent sport that draws children's attention to practice, which is beneficial to them in terms of their acquisition of good strength and educational values, as well as the development of physical, skill, psychological and social abilities, giving them the ability to create, 17) $(98: 27)$

Gymnastics provides an opportunity for children to create the ability to innovate and to achieve satisfaction and happiness when successful in the performance of formations and the implementation of the movements of constituents, which leads to the development of the ability to reflect consistency and continuity and harmony and balance, and also develops awareness of the need for strength and skin to complete some movements Innovative in Gymnastics 
The development of courage, courage, and selfconfidence through proper pedagogy through the education of the group of reptiles can be the first step in teaching ground movements because of their ease and relevance to the ability of children (41: 5)(8)entitled

"The effect of the purpose games on some physical variables and the level of performance of some ground skills in gymnastics and loneliness for the hearing impaired" and the study of Raja Sharif Allam (2005) (9). (1997) (10) entitled "The Effectiveness of a Proposed Sports Activity Program on the Development of Achievement, Consensus and the Fixed Balance of Children with Hearing Impairments" and the Study of Alia Abdul-Moneim Ibrahim (2012) (16) entitled

"The impact of using multimedia on learning Some of the basic skills and some physical variables in deaf and dumb children, which indicate the importance of practicing physical exercises for normal children in general and those with disabilities, in particular, as evidenced by many studies and studies such as the study of
Marco Morkovin \& Bori (2003), Roy Roy (1999) (27) ), Where deaf children outperform ordinary children in the speed of running, muscular strength and visual control, and interest in sports gymnastics and the status of advanced for various sports activities, it is an individual sport that earns the child self-reliance and provide opportunities to control and control the body parts through the rich activities of Games and the content of a variety of basic skills commensurate with childhood jumps and somersaults and spins and the skills of balance and compatibility kinetic stage, and this prompted the researcher to conduct this study to identify the impact of the use of gymnastics games at the level of social interaction and the level of fitness and motor learning some gymnastics skills in children with disabilities acoustically.

\section{Research goal}

The aim of the research is to identify the effect of the use of gymnastics on the level of social interaction and the level of fitness in children with hearing impairment.

\section{Research hypotheses}


-There are statistically significant differences between the averages of pre and post measurements in the level of social interaction among children with hearing disabilities.

-There were statistically significant differences between the averages of pre and post measurements in the level of physical fitness of children with hearing impairments.

-There are statistically significant differences between the averages of pre and post measurements in the level of learning some skills of ground movements in children with hearing impairment.

\section{Research plan and procedures}

\section{First: Research Methodology}

The researcher used the experimental method using measurements (pre and post) on one experimental group, in order to suit the nature of this research.

\section{Table (1)}

The homogeneity of the research sample members in the search variables $N=15$

\begin{tabular}{|c|c|c|c|c|c|c|}
\hline Variables & \multicolumn{2}{|c|}{ Measure unit } & SMA & $\begin{array}{l}\text { standard } \\
\text { deviation }\end{array}$ & Mediator & $\begin{array}{c}\text { Torsion } \\
\text { coefficient }\end{array}$ \\
\hline$\overline{\text { Height }}$ & \multicolumn{2}{|c|}{$\overline{\mathrm{Cm}}$} & 132.2 & 1.7 & 132 & 0.35 \\
\hline Weight & \multicolumn{2}{|c|}{$\mathrm{Km}$} & 31.9 & 1.38 & 32 & -0.22 \\
\hline Age & \multicolumn{2}{|c|}{ Year } & 10.78 & 0.80 & 11.00 & -0.83 \\
\hline \multirow{2}{*}{$\begin{array}{l}\text { Hearing } \\
\text { level }\end{array}$} & Right ear & DB & 71.02 & 1.25 & 71.00 & 0.048 \\
\hline & Left ear & DB & 72.36 & 1.36 & 72.00 & 0.794 \\
\hline \multirow{2}{*}{$\begin{array}{l}\text { Social } \\
\text { interactions } \\
\text { withdrawal } \\
\text { behavior }\end{array}$} & $\begin{array}{c}\text { Social } \\
\text { interactions }\end{array}$ & Degree & 35.85 & 35.80 & 1.52 & 0.0010 \\
\hline & $\begin{array}{c}\text { Withdrawal } \\
\text { behavior }\end{array}$ & Degree & 48.21 & 48.20 & 1.69 & 0.0035 \\
\hline \multirow{3}{*}{$\begin{array}{l}\text { Physical } \\
\text { variables }\end{array}$} & Slant angle & No & 4.9 & 5 & 1.87 & 1.01 \\
\hline & $\begin{array}{c}\text { Numbered } \\
\text { circle }\end{array}$ & $\mathrm{S}$ & 14.2 & 14 & 1.24 & -0.74 \\
\hline & $\begin{array}{c}\text { The } \\
\text { running for } \\
30 \text { meters }\end{array}$ & $S$ & 9.5 & 9 & 1.36 & 0.50 \\
\hline
\end{tabular}

\section{Follow Table (1)}

The homogeneity of the research sample members in the search variables $N=15$ 


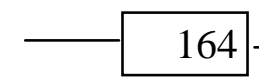

\begin{tabular}{c|c|c|c|c|c|c}
\hline Variables & \multicolumn{2}{|c|}{ Measure unit } & SMA & $\begin{array}{c}\text { standard } \\
\text { deviation }\end{array}$ & Mediator & $\begin{array}{c}\text { Torsion } \\
\text { coefficient }\end{array}$ \\
\hline \hline \multirow{7}{*}{$\begin{array}{c}\text { Technical } \\
\text { variables }\end{array}$} & $\begin{array}{c}\text { Bend the } \\
\text { trunk from } \\
\text { the stand }\end{array}$ & Cm & 3.5 & 4 & 1.21 & -0.59 \\
\cline { 2 - 7 } & $\begin{array}{c}\text { Front } \\
\text { Rolling }\end{array}$ & Degree & 1.52 & 1.50 & 0.12 & 1.50 \\
\cline { 2 - 7 } & $\begin{array}{c}\text { Back } \\
\text { Rolling }\end{array}$ & Degree & 1.62 & 1.60 & 0.14 & 1.60 \\
\cline { 2 - 7 } & $\begin{array}{c}\text { Rolling } \\
\text { The front }\end{array}$ & Degree & 1.28 & 1.25 & 0.32 & 1.25 \\
\cline { 2 - 7 } & $\begin{array}{c}\text { The back } \\
\text { balance }\end{array}$ & Degree & 1.32 & 1.30 & 0.14 & 1.30 \\
\hline \hline
\end{tabular}

It is clear from Table (1) that the torsion coefficient is limited to $(-0.83,1.60)$. This means that the variables achieve the average curve, which is limited to +3 , which confirms the degree of homogeneity between the sample members as a whole.

\section{Tools used in research:}

A - Rustameter: to measure the length of the nearest half $\mathrm{a} \mathrm{cm}$. B - Medical balance: to measure the weight of the nearest half-km.

C - Balloons.

D - Ping Pong balls.

E. Long rope width of bathroom.

Large plastic collars.

$\mathrm{G}$ - Long sticks.
(H) Instrument of ground movements

I - Floating plates.

$\mathrm{J}$ - Small games float.

K-Balls are great.

Swedish Seat.

M-tape paste.

Tests and measurements used in research:

. The social interaction scale for children aged 5-12 years was prepared by Adel Abdullah (2001). The coefficients of honesty were 0.79 and 0.681 respectively. Annex (5)

- $r$ the measure of withdrawal behavior for children from the age of (5: 12) year prepared by Adel Abdullah (2001) and amounted to the coefficients of honesty 0.763 and stability of 
0.743 on the Egyptian environment. Annex (6)

Physical Tests (2)

*Tilt test slant to measure muscle strength.

- *Digital circuit test to measure compatibility level.

r. - *meters running test for speed level measurement.

- *Test the torso of the stand to measure the level of flexibility.

. Technical tests (Annex 3)

*Test front roll.

* Background rolling test.

* Side rolling test.

*Front balance test.

*Test the back balance.

- ${ }^{\circ}$ Expert consultation

questionnaire on the

dimensions of the proposed program for gymnastics.

Annex (4)

'Tist of experts. Annex 1.

. $)$ Proposed program. Annex

7.

Proposed Program:

Program Objective

The program aims at identifying the effect of the use of gymnastics on the level of social interaction and the level of motor fitness and learning some gymnastics skills in children with hearing disabilities.

\section{Program Contents- :}

The researcher designed the proposed games program for the hearing impaired and took care to suit the characteristics, trends and needs of the sample commensurate with their abilities, abilities and preparations. The researcher used the tools available or without them, and most of the exercises are done collectively to achieve the goal of the program and improve the level of social interaction.

The program has a direct impact on the development of physical qualities and improve the level of performance of some ground skills in gymnastics and reduces the sense of isolation and sense of unity, and took into account in the program to contain the games beloved to the souls of the research sample and lead These games to reduce the sense of loneliness and tendency to gather and be free of complexity and enter the joy and pleasure to them.

Daily module content- :

Warm-up: - (10) minutes

The goal is to prepare the body and muscles for performance and gradual transition to the basic training period and this period should not be neglected to prevent injuries at the 
beginning of each training module daily.

The main part: - (45) minutes

It is one of the most important periods of the program because it works to achieve the goal of the program and contains a period of a set of gymnastics games.

Calming: - (5) minutes

The goal is to return the body and its organs to the normal state gradually at the end of each training module daily Implementation of the program:

The researcher applied the proposed program for gymnastics in the period from $10 / 6 / 2016$ to $5 / 8 / 2016$ on the basic sample for two months at 8 weeks and 3 training units per week in 60 minutes divided into 10 minutes. Warm-up - 45 minutes gymnastics exercises 5 minutes cool down), and the researcher has fixed time throughout the program.

\section{Dimension measurements:}

The measurements were carried out in the period from $7 / 8 / 2016$ to $10 / 8 / 2016$ on the research sample in all variables under the following order (physical variables - level of performance of some ground skills - social skills) taking into account the availability of the same conditions and conditions of application they were followed in pre measurements View and discuss results Showing results:

\section{Table (2)}

The significance of the differences between the pre and the post measurements in the scale of (socio- Withdrawal behavior) in children sample research $N=15$

\begin{tabular}{|c|c|c|c|c|c|c|c|c|}
\hline \multirow{2}{*}{ Variables } & \multicolumn{2}{|c|}{ Pre measure } & \multicolumn{2}{|c|}{$\begin{array}{c}\text { Post } \\
\text { measure }\end{array}$} & \multirow{2}{*}{$\begin{array}{c}\mathbf{T} \\
\text { value }\end{array}$} & \multirow{2}{*}{$\begin{array}{c}\text { Differences } \\
\text { between } \\
\text { the two } \\
\text { averages }\end{array}$} & \multirow{2}{*}{ Change\% } & \multirow{2}{*}{$\begin{array}{c}\text { Functional } \\
\text { level }\end{array}$} \\
\hline & $\mathbf{M}$ & $\mathbf{E}$ & M & $\mathbf{E}$ & & & & \\
\hline $\begin{array}{l}\text { Social } \\
\text { interactions }\end{array}$ & ro. & $1.0 r$ & 70.10 & .10 & $r .91$ & $r \cdot .$. & \%^ґ.ィ人 & Significance \\
\hline $\begin{array}{l}\text { Withdrawal } \\
\text { behavior }\end{array}$ & $\{\Lambda, r\}$ & 1.79 & r.or & ro & $r .01$ & 17.79 & $\%$ or.90 & Significance \\
\hline
\end{tabular}

The value of the "t" of the table at a significant level of $0.05=2.16$

Table (2) shows that there are statistically significant differences in favor of post-pre measurement of the research sample in measures (social interactions - withdrawal behavior.) 
Table (3)

Significance of differences between pre and post measurements in some physical variables $N=15$

\begin{tabular}{|c|c|c|c|c|c|c|c|c|c|}
\hline \multirow{2}{*}{$\begin{array}{l}\text { Physical } \\
\text { variables }\end{array}$} & \multirow{2}{*}{$\begin{array}{l}\text { Physical } \\
\text { variables }\end{array}$} & \multicolumn{2}{|c|}{$\begin{array}{l}\text { Pre } \\
\text { measurement }\end{array}$} & \multicolumn{2}{|c|}{$\begin{array}{l}\text { Post } \\
\text { measurement }\end{array}$} & \multirow{2}{*}{$\begin{array}{l}\text { Differences } \\
\text { between } \\
\text { the two } \\
\text { averages }\end{array}$} & \multirow{2}{*}{ Change\% } & \multirow[t]{2}{*}{$\begin{array}{l}\text { T } \\
\text { value }\end{array}$} & \multirow{2}{*}{$\begin{array}{l}\text { Function } \\
\text { level }\end{array}$} \\
\hline & & $\mathbf{E}$ & $\mathbf{M}$ & $\mathbf{E}$ & $\mathbf{M}$ & & & & \\
\hline $\begin{array}{l}\text { Slant } \\
\text { angle }\end{array}$ & No & 4.9 & 1.87 & 8.20 & 2.10 & 3.30 & $67.34 \%$ & $7.20 *$ & Significance \\
\hline $\begin{array}{l}\text { Numbered } \\
\text { circuits }\end{array}$ & $\mathbf{S}$ & 14.2 & 1.24 & 10.3 & 2.58 & 3.90 & $37.86 \%$ & $8.50 *$ & Significance \\
\hline $\begin{array}{l}\text { The } \\
\text { enemy for } \\
\text { is } \quad 30 \\
\text { meters } \\
\end{array}$ & $\mathbf{S}$ & 9.5 & 1.36 & 7.5 & 1.90 & 2.00 & $26.66 \%$ & $4.62 *$ & Significance \\
\hline $\begin{array}{l}\text { Bend the } \\
\text { trunk of } \\
\text { the stand }\end{array}$ & $\mathrm{Cm}$ & 3.5 & 1.21 & 4.10 & 2.54 & 0.60 & $17.14 \%$ & $6.25^{*}$ & Significance \\
\hline
\end{tabular}

The value of the " $t$ " of the table at a significant level of $0.05=2.16$

Table (3) shows statistically significant differences in favor of postpre measurement of the research sample in some of the physical variables under study.

\section{Table (4)}

Significance of differences between pre and post measurements in some skill variables $N=15$

\begin{tabular}{|c|c|c|c|c|c|c|c|c|c|}
\hline \multirow{2}{*}{$\begin{array}{l}\text { Physical } \\
\text { variables }\end{array}$} & \multirow{2}{*}{$\begin{array}{l}\text { Measure } \\
\text { unit }\end{array}$} & \multicolumn{2}{|c|}{$\begin{array}{c}\text { Pre } \\
\text { measure }\end{array}$} & \multicolumn{2}{|c|}{$\begin{array}{c}\text { Post } \\
\text { measure }\end{array}$} & \multirow{2}{*}{$\begin{array}{c}\text { Differences } \\
\text { between } \\
\text { the two } \\
\text { averages }\end{array}$} & \multirow{2}{*}{ Change \% } & \multirow[t]{2}{*}{$\begin{array}{c}\mathbf{T} \\
\text { value }\end{array}$} & \multirow{2}{*}{$\begin{array}{c}\text { Function } \\
\text { level }\end{array}$} \\
\hline & & $\mathbf{E}$ & M & $\mathbf{E}$ & M & & & & \\
\hline $\begin{array}{l}\text { Front } \\
\text { Rolling }\end{array}$ & Degree & 1.52 & 0.12 & 2.80 & 0.29 & $45.71 \%$ & 1.28 & 3.85 & Indicted \\
\hline $\begin{array}{l}\text { Back } \\
\text { Rolling }\end{array}$ & Degree & 1.62 & 0.14 & 2.66 & 0.17 & $39.09 \%$ & 1.04 & 3.24 & Indicted \\
\hline $\begin{array}{l}\text { Side } \\
\text { Rolling }\end{array}$ & Degree & 1.28 & 0.32 & 2.39 & 0.32 & $46.44 \%$ & 1.11 & 3.96 & Indicted \\
\hline $\begin{array}{l}\text { The front } \\
\text { balance }\end{array}$ & Degree & 1.32 & 0.14 & 2.51 & 0.28 & $47.41 \%$ & 1.19 & 3.54 & Indicted \\
\hline $\begin{array}{l}\text { The back } \\
\text { balance }\end{array}$ & Degree & 1.25 & 0.16 & 2.48 & 0.21 & $49.59 \%$ & 1.23 & 3.87 & Indicted \\
\hline
\end{tabular}

The value of the " $t$ " of the table at a significant level of $0.05=2.16$

Table

(4) shows

sample in some of the technical

statistically

significant

variables under study.

differences in favor of post-pre

Discussion of results

measurement of the research

Assiut Journal For Sport Science Arts 
The results of Table (2) show that there are statistically significant differences in favor of post-pre measurement in the social interaction scale. The researcher attributed this improvement to the fact that the gymnastics program contained a variety of competitive activities, which helped the children to establish relationships among colleagues and acquire some social abilities, Social relations and increased capacity to communicate with the surrounding.

These results came in line with the results of Adel Abdullah and Mona Khalifa (2002), 13 which pointed to the importance of games in various forms in the early stages of the age are the basis for the development of children obese, socially, mentally and psychologically.

Abdul- Hamid Sharaf (2003) states that whenever a disabled child is small, the more active his activity and the exercise of motor games without educational guidance. Through movement, games and multicolored sports practice, the child has the opportunity to contact children in the same age, among children each other at this stage (15: 80)

That the hearing impaired are considered to be the category that has suffered and continues to suffer from the deprivation of enjoyment of life with the normal, because hearing is a means to be recognized by the human being in his social environment, that is, a class that develops its life without having full communication or cooperation with the environment on an audio basis (27: 95)

These results are also consistent with the De Kegel study (2010), 24 (Maurice, 2002). They note the importance of motor, recreational and play activities in reducing undesirable behaviors, avoiding closure and isolation, and reducing their withdrawal behavior.

The results of this study are consistent with Hamida Abdullah (2011), Raja Allam (2005), and Magda Khader (2007). All the results of this study indicate the importance of exercise in improving the psychological and social skills of the disabled Audio.

Thus, the first hypothesis of the research, which states that there are 
statistically significant differences between the averages of pre and post measurements in the level of social interaction among children with hearing disabilities

The results of Table (3) show the existence of statistically significant differences between the pre and the post variables in the physical variables in favor of the telemetry through the program that contains the gymnastics skills of the games. The researcher attributed this improvement to the use of the proposed program for gymnastics and the gradualization of these games from simple to the average and inclusion of the program on individual, marital and group games that helped these children increase social interaction with their peers and decrease their withdrawal behavior

The researcher explained the improvement in the physical variables to the ability of the gymnastics program proposed to develop the elements of fitness as the exercises used in the program has helped to develop physical variables and increase the sense of direction and increase the ability to balance, whether during the stability or movement and helped to a large extent to develop compatibility Mobility and flexibility and increase the individual's sense of the situation and the place in which it moves.

The researcher also pointed out that the gymnastics of the games, which are small games and group exercises in the form of competitions and exercises such as natural crawling, skiing and attachment exercises and jumping and jumping and lifting exercises and balance and made them feel happy and happiness and freedom of movement and overcome fear and develop the sense of movement and gradual in the tools and rotation between the speed and ease of exercise Which leads to a sense of happiness and courage, selfconfidence, teamwork and physical and skill development. The results of this study are consistent with the positive effect of sports activities on this group with the study of Hamida Abdullah (2011), 8 Manar Shahin Abdel Rahman, Omaima Hassanein Hijazi 
(2003), 22 Hala Mohammed Aliwa (2004) That sports programs and activities and their multiple forms have a positive impact on the advancement and advancement of this group and help to solve their physical and psychological problems.

These findings also correlate with what Alia Abd Al-Moneim (2012) (16) Hamida Abdalla (2011) 8 indicate that physical activity is particularly important for the hearing impaired, as it inspires them to be active, Helps them achieve the overall fitness of the body.

This confirms the validity of the second hypothesis, which states that there are statistically significant differences between the averages of pre and post measurements in the level of fitness of children with hearing impairments.

The results of Table (4) show the existence of statistically significant differences between the pre and post criteria in the skill variables of the ground movement skills in favor of telemetry through the program that contains the gymnastics skills of the games. The researcher traces this progress in the level of performance of some ground skills for gymnastics Gymnastics games and the contents of the exercises that help them to feel satisfaction and satisfaction and collective behavior and pleasure and pleasure and selfarousing to the self as it instills respect and friendship among students and the speed and ease of learning and performance.

In this regard, Amine Al-Khouli and Osamah Rateb (1998) point to the importance of practicing sports, where the child is freed from his problems and becomes a more liberal, spontaneous and consensual child (74: 4)

These results are in line with Adil's "Saad Shenouda", "Samia Farghali Mansour" (2002) that the purpose games are to develop the learner's performance of motor skills in various sports activities, which increases his tendency to practice sports activity and improve his level and abilities.: 5 Thus achieving the validity of the third hypothesis, this states that there are differences of statistical significance between the averages of pre and post measurements in the level of 
learning some skills of ground movements in children with hearing disabilities

\section{Conclusions:}

1-The use of gymnastics program of the Games led to improved social interactions of children with hearing disabilities.

2-The Games Gymnastics program has reduced the withdrawal behavior of children with hearing disabilities.

3-Gymnastics program of the Games led to the acquisition of some physical abilities of children with hearing disabilities.

4-Gymnastics program of the Games led to the acquisition of some of the skills of motor gymnastics of the movements of land for children with hearing impaired.

\section{Recommendations:}

1-Benefiting from the proposed program because of its positive impact on the development of basic skills and social disorders and withdrawal behavior and make it an essential part within the treatment programs.

2- the need to conduct similar studies on the different stages of the age of the hearing impaired and the design of multiple remedial programs by specialists in various fields.

3- Provide the opportunity for this group to connect and participate in various activities and sports and recreational activities based on scientific grounds to help them integrate into society.

\section{References}

\section{1-Adel Abdullah Mohammed} (2000): "The effectiveness of a training program to develop communication skills on some behavioral aspects of children of the deviant", Journal of Faculty of Education Zagazig, No. (23), Egypt.

\section{2- Adel Abdullah}

Mohammed, (2002): measure of social interactions of children outside the home for children with special needs, Dar al-Rashad, Cairo.

\section{3- Abdel- Hamid Sharaf} (2003): Physical and motor education for children with disabilities and disability, the book center for publishing, Cairo.

4- Adil Saad Shenouda, Samia Farghali Mansour (2002): "Artistic Gymnastics, 
Concepts, Applications", Forum of Thought, Alexandria.

5-Ahmed Hussein Al-Lakani, Amir Al-Qurashi (1999): Deaf curricula planning, construction and implementation, World Books, Cairo.

6- Amani Abdel Maqsoud Abdel Wahab (B): a measure of the appreciation of social skills for children, the AngloEgyptian Library, Cairo.

7-Amin Anwar Al-Khouli, Osama Kamel Rateb (1998): Pediatric Education of the Child, Fifth Edition, Dar AlFikr Al-Arabi, Cairo.

8- De Kegel A., Dhooge I., Peersman W., Rijckaert J., Baetens T., Cambier D. and Van Waelvelde H. (2010): "Construct Validity of the Assessment of Balance in Children Who Are Developing Typically and in Children With Hearing Impairments"; Physical Therapy, 90, 1783-1794

9- Elia Abdel- Moneim Ibrahim (2012): The Effect of Using Multimedia on Learning Some Basic Skills and Some Physical Variables in Deaf and Mute Children, Published Scientific Research, Journal of Science and Arts of Physical
Education, Faculty of Physical Education, Assiut University

10-Fawzi Rizkallah, Adel Abdul Basir (2000): theories and scientific foundations in gymnastics training, Modern Book House, Cairo.

\section{1-Hala Mohammed Aliwa} (2004): Suggested program in sign language to develop the kinetic abilities associated with ground movements in artistic gymnastics for young people with special needs (Deaf and Mute), unpublished $\mathrm{PhD}$ thesis, Faculty of Physical Education for Girls, Alexandria University.

\section{2-Hamida Abdullah Attieh} Khadraji (2011): The Effect of Targeted Games on Some Physical Variables and the Level of Performance of Some Ground Skills in Gymnastics and Loneliness for the Hearing Impaired, Scientific Research Published, Scientific Journal of Physical Education and Mathematical Sciences, No. (62) January, Helwan University.

13- Hassan Al-Bata Abdul Ati (2010): Educational Technology for Special Needs, 
Knowledge Magazine Ain Shams University, Cairo.

14- Helmi Mohamed Ibrahim, Laila El-Sayed Farahat (2008): Physical Education and Recreation for the Disabled, Arab Thought House, Cairo.

\section{5-Magda Khadr (2007)}

Suggested program in the sign language to develop some of the motor abilities and the ability to perform the skills of the frontal hump (humping horse) for children deaf and dumb, Journal of Sports Sciences vol.

16-Manar Shahin AbdelRahman, Omaima Hassanein Hegazi (2003): Effect of Gymnastics Program on Physical Adaptation and Attention Disorders and Social Interactions of Autistic Children, Specialized Scientific Journal of Physical Education, Faculty of Physical Education, Assiut University.

\section{7- Maurice R.et al:} "Validation and calibration of physical Activity monitors in children" the North American Association for the study of obesity Research 10, 150-1572002.
18- Mohamed Bayoumi Khalil (2003). The Effect of a Proposed Exercise Program on Some Physical Characteristics of Deaf and Mute, Unpublished Master Thesis, Faculty of Physical Education for Girls, Zagazig University.

19- Mohamed El Sayed Abdel Rahman (1998): Social Skills and its Relation to Depression and Despair in Children, Studies in Mental Health, Part II, Dar Kebaa, Cairo.

\section{0- Mohamed Fathy Hussein} (2004): "Effect of a program of motor education on the performance of some special motor skills for deaf mute (6-9 years), Master Thesis, Faculty of Physical Education, Mansoura University.

21-Morkovin, Boris v., (2003) ;Encyclopedia Americana Teaching Language to deaf children U.S.A.

\section{2- Mr. Ibrahim Al-} Samadouni (P.): Social Skills Scale, The Anglo-Egyptian Library, Cairo.

23-Raja Sharif Allam (2005):

A proposed program for the development of some forms of positive social behavior of the 
deaf child, unpublished doctoral thesis, Institute of Educational Studies and Research, Cairo University.

24-Reza Mustafa Asfour (1997): "The effectiveness of a proposed sports activity program on the development of scholastic achievement, harmony and steady balance of hearing impaired children," the second scientific conference, Faculty of Physical Education Zagazig University.
25- Roy, j. Scephard (1999); Fitness in special population human kinetics boo's.

26-Sahar Zidan Shehata (2008): The Psychology of the Deaf Child, Itrak Publishing, Publishing and Distribution, Cairo.

27- Shaheen Raslan Shahin (2009): The Psychology of Mental and Sensory Disabilities, The AngloEgyptian Library, Cairo. 